\title{
Multimodal ve unimodal taşımacılık için rota karşılaştırılması: Hatay-Tekirdağ vaka analizi
}

\author{
Ömer Faruk CANSIZ, Kevser ÜNSALAN* \\ İskenderun Teknik Üniversitesi, Mühendislik ve Doğa Bilimleri Fakültesi, İnşaat Mühendisliği Bölümü, \\ Merkez kampüsü, Hatay \\ Geliş Tarihi (Received Date): 28.12 .2018 \\ Kabul Tarihi (Accepted Date): 11.12.2019
}

Öz

Çalışmada, konteyner yük taşımacılı̆̆ için güzergâh karşılaştırılması yapılmaktadır. Unimodal ve multimodal taşımacılık modu incelemesinin yanı sıra farklı güzergâh seçim kriterleri de ele alınmaktadır. Bu kriterler yakıt tüketimi, maliyet, taşıma süresi ve karbondioksit salınımı olmak üzere dört kategoride değerlendirilmektedir. Dört değerlendirme kriteri dikkate alınarak parasal ve parasal olmayan giderlerin toplamı olan genelleştirilmiş maliyet değerleri hesaplanmaktadır. Rotaları değerlendirmek için yükün Hatay'dan Trakya bölgesindeki Tekirdăg'a taşındı̆̆ l kabul edilmektedir. Bu iki nokta arasinda karayolu, demiryolu ve denizyolu olmak üzere üç unimodal ve bu taşımacılık türlerinin kombinasyonlarından oluşan dört farklı multimodal taşımacılık rotası oluşturulmaktadır. Geliştirilen rotaların genelleştirilmiş maliyetleri incelendiğinde \%94,35- \%72,43 performans araliğ ile optimum güzergah demiryolu çıkmaktadır. En verimsiz güzergâh ise \%59,27-33,01 performans aralığı ile karayolu rotasıdır. Multimodal taşımacılık rotalarında tür değişim noktalarında yaşanan mali ve zamansal kayıplardan dolayı verimlilik düşmektedir.

Anahtar kelimeler: Multimodal taşımacılık, unimodal taşımacılık, rota karşılaştırılması.

\section{Comparison of routes for multimodal and unimodal transport: Hatay-Tekirdag case analysis}

\begin{abstract}
In the study, comparison of route is studied for container freight transportation. In addition to unimodal and multimodal mode, different route selection criteria are

Ömer Faruk CANSIZ, ofaruk.cansiz@iste.edu.tr, http://orcid.org/0000-0001-6857-2513

*Kevser ÜNSALAN, kevser.keskin@iste.edu.tr, http://orcid.org/0000-0002-9163-4855
\end{abstract}


discussed. These criteria are evaluated in four categories: fuel consumption, cost, transportation time and carbon dioxide emission. The generalized cost values, which are the sum of monetary and non-monetary expenses, are calculated by taking into consideration the four evaluation criteria. In order to evaluate the routes, it is considered that the freight was moved from Hatay to Tekirdag in the Thrace region. Between these two points, four different multimodal transportation routes are formed using three unimodal road, rail and sea transport and a combination of these transportation modes. When the generalized cost of the developed routes are examined, the optimum route is the railway route with the performance range of $94,35 \%$ to $72,43 \%$. The most inefficient route is road transport with a range of 59,27\% to 33,01\% generalized cost. In multimodal transport routes, efficiency is reduced due to the financial and temporal losses experienced in transportation mode change points.

Keywords: Multimodal transport, unimodal transport, comparison of route.

\section{Giriş}

Yük taşımacılığında optimizasyon uzun süredir araştırılan konulardan biridir. Unimodal ve multimodal rotaların optimizasyonu ise az çalışılan konulardandır. Geleneksel ve sezgisel algoritmalar ile bu konuda çeşitli optimizasyon çalışmaları yapılmaktadır [1]. Geleneksel ve sezgisel algoritmaların oluşturulması için öncelikle unimodal ve multimodal taşımacılıkla ilgili parametrelerin iyi belirlenmesi gerekmektedir [2]. Özellikle multimodal taşımacılığa ait özelliklerin coğrafi şartların getirdiği zorunluluklar dikkate alınarak gerçekçi bir şekilde algoritmalara yerleştirilmesi doğru çözüme ulaşılması için kaçınılmazdır [3,4,5].

Cansız ve Polat, Hatay'daki mevcut ulaşım altyapısını incelemiş ve verimliliği arttırmak için önerilerde bulunmuşlardır [6]. Taşımacılıkta verimliliği artırabilmek için başka bir çalışmada, karayolu trafik yoğunluğunun fazla olduğu Marmara Bölgesindeki karayolu taşımacılığının kombine taşımacılığa aktarılması ile mevcut karayolu taşımacılığı yoğunluğunun azaltılmasına katkı sağlanacağı öne sürülmektedir [7]. Öztürk, Türki Cumhuriyetlerle yaptığı ihracata yönelik taşımacılıkta maliyet analizi yaparak kombine taşımacılığa yönelik olumlu bulgular elde etmektedir [8]. Diğer bir çalışmada, kombine taşımacılıkta mevcut alt yapı analizi yapılarak, liman seçiminde gerekli özellikler vurgulanmaktadır. Analizler sonucu kombine taşımacılıkta ülkemizde deniz ve demiryolu uyumu araştırılmakta ve olumsuz veriler elde edilmektedir. Bu hususta kombine taşımacılığın olumlu ve olumsuz yanları belirlenmektedir [9]. Steadieseifi vd. çalışmalarında multimodal taşımacılığın lojistik platformda güvenilir, verimli ve sürdürülebilirlik açısından birçok avantajı beraberinde getirdiğini vurgulamaktadır. Ayrıca multimodal taşımacılığın alt kollarından oluşan yük taşımacılığı terminolojisi için birçok kavram için araştırma yapmaktadır Çalışmasında multimodal taşımacılık üzerine yapılan çalışmaları stratejik, taktiksel ve operasyonel olmak üzere üç grupta değerlendirmektedir [10].

Vural vd. yer seçimi rotalama problemi ile demiryolu ve karayolu kombinasyonundan oluşan multimodal taşımacılık senaryosu geliştirerek mevcut durum karşılaştırması yapmaktadır [11]. Atar vd. çalışmalarında kısa mesafe deniz taşımacılığı ile birlikte kombine taşımacılığın önemini çeşitli parametrelere bağlı olarak vurgulamaktadır. Dinamik olarak değişen ekonomik koşullar, yük taşımacılığındaki artan talebi 
etkilemektedir. Kaçınılmaz olarak, ağır ve büyük boy yük taşımacılığına olan talep artmaktadır [12]. Petraska vd. ağır ve büyük boyutlu yüklerin taşınmasında farklı kriterler üzerinden multimodal taşımacılığı araştırmaktadır [13]. Woo vd. otomotiv sanayisi ile küresel ticarete açılan Kore için lojistik maliyetlerini düşürecek yeni yöntemler aramış ve Kore-Amerika arasında dört farklı multimodal ulaşım ağı geliştirmişlerdir. Geliştirdikleri bu ulaşım ağlarının yıllık maliyet olarak karşılaştırmasını yapmışlardır. Kanada'nın doğu bölgelerinin petrol ihtiyacı sadece denizyolu ağları ile yapılmaktadır. Denizyoluna bu denli bağımlılık, denizyollarında yoğun trafiğe ve çok fazla petrol sızıntılarına yol açmaktadır [14]. Basu ve Verma, bölgenin coğrafi şartlarını değerlendirerek denizyolu ve demiryolu kombinasyonlu petrol taşıma güzergâhları araştırılmakta ve bunun için Kanada'da bir vaka analizi çalışması yapılmaktadır [15]. Hanssen vd. Norveç'te taze balık nakliyesinde, uzun mesafe taşımacılıkta karayolu taşımacılığının bulunmadığı intermodal taşımacılığın yapılabilmesi için gerekli mesafe optimizasyonu üzerine öneriler sunmaktadır. İntermodal taşımacılık ile birlikte karayolu taşımacılığından kaynaklı sürücü giderleri, dinlenme masraflarının bertaraf edildiği görülmektedir. Çalışma sonucunda intermodal taşımacılık yapılması durumunda ve aksi durumda fayda-zarar ilişkisi analiz edilmektedir. Genel tablo incelendiğinde Norveç'ten Avrupa kıtasına taze balık nakliyesi için intermodal taşımacılığın yapılması için gerekli mesafenin yeterli olduğu ve karayolu taşımacılığından ziyade intermodal taşımacılığın yapılmasının daha uygun olduğu kararına varılmaktadır [16]. Janic karayolu ve intermodal taşımacılık maliyet karşılaştırması için model geliştirmiştir. Geliştirilen modelde yük miktarı arttıkça intermodal taşımacılıkta maliyetlerin azaldığı gözlemlenirken, karayolu maliyetlerinin sabit kaldığı görülmektedir [17].

Du vd. gemicilerin rota seçim kararları, yük kapasitesi, navlun taşıma sistemini, denizyolu üzerindeki su seviyesi değişiminin etkilerini araştırmış ve multimodal taşımacılık ağının nasıl kullanılacağına ve gerçekleştirileceğine dair bilgiler sağlamışlardır. Genel amaçları devam etmekte olan iklim değişikliği etkileri karşısında etkin bir yük taşımacılığı ağını sürdürmek için altyapı yatırım kararları ve iş durumlarının geliştirilmesi için rehberlik sağlamaktır [18]. Fremont ve Franc Fransa'da karayolunun demiryoluna kayma potansiyelini değerlendirmişlerdir ve intermodal taşımacılığın limandan en az 200 kilometre uzaklıkta gidiş geliş seyahatleri için efektif çıktığını belirtmişlerdir [19]. Arnold vd. İspanya'daki minimum intermodal taşımacılık mesafesini değerlendirmek için bir model geliştirmişlerdir. 500 kilometrenin altındaki mesafelerde intermodal taşımacılığın maliyet açısından uygun çıkmadığı sonucuna varmışlardır [20].

Bu çalışmada yurtiçi taşımacılıklarda yaygın kullanım alanı olan unimodal taşımacılık yerine kıtalar arası taşımacılıkta yaygın olan multimodal taşımacılığın tercih edilmesindeki kıstaslar vurgulanmaya çalışılmaktadır. Unimodal taşımacılıkta ulaşım coğrafyasından kaynaklı kısıtlar, multimodal taşımacılık ile beraber aşılmaya çalışılmaktadır. Böylelikle unimodal taşımacılık anlayışının yerine multimodal taşımacılık anlayışı benimsenmeye çalışılmaktadır. Taşımacılık modlarının karşılaştırılabilmesi için filtre malzemesi üretiminin yaygın olduğu Hatay ilinden Trakya bölgesinde yer alan Tekirdağ illeri seçilerek unimodal ve multimodal taşımacılık rotaları oluşturulmaktadır. Rotalar firmaların tercih sebepleri ve literatürdeki çalışmalar dikkate alındığında maliyet ve zaman kıstası dikkate alınmaktadır. Son dönemlerde sürdürülebilir çevre anlayışının gelişmesi ve hükümetlerin de bu konu üzerine yeni vergi sistemlerini uygulaması üzerine yakıt tüketimi ve taşıma araçlarından salınan $\mathrm{CO}_{2}$ 
miktarları da incelenmektedir. Her bir kıstas ayrı ayrı göz önünde bulundurulurken, hepsinin birden değerlendirilmesi için genelleştirilmiş maliyet hesaplanmakta ve rotalar dört kritere göre eş zamanlı değerlendirilmektedir.

\section{Materyal metod}

\subsection{Yakıt tüketimi hesabı}

Enerji kaynakları yenilenebilir ve yenilenemez olmak üzere ikiye ayrılmaktadır. Araç yakıtı olarak kullanılan petrolün yan ürünleri yenilenemez enerji kaynakları içerisine girmektedir. Türkiye'de petrol ürünlerinin ulaştırma içerisinde kullanımı 2.807.997 TEP ve tüm sektörlere oranı \% 11,19 dur [21]. Ulaştırmadaki enerji tüketiminin önemli bir paya sahip olması nedeniyle, güzergâhların performansını değerlendirmede yakıt tüketimi, önemli bir kıstas olarak ele alınmaktadır.

\section{Karayolu yaklt tüketimi}

Karayolu taşımacılığında taşıtın yüklü gittiği ve geri dönüşte taşıtın başka yükler taşıdığı kabul edilmektedir. Bu nedenle taşıtın geri dönüşte tükettiği yakıt miktarı hesaplara dâhil edilmemektedir. Taşıtın yük taşıma kapasitesine bağlı olarak yakıt tüketimi hesaplanmaktadır. Araç 26 ton tam kapasite ile dolu iken 40 litre yüksüz iken ise 30 litre yakıt tüketmektedir[22]. Karayolu yakıt tüketimi Denklem 1 dikkate alınarak bulunmaktadir.

$Y T_{\text {karayolu }}=\left((\mathrm{YM}) /(\mathrm{MY}) \times\left(\mathrm{YT}_{\max }-\mathrm{YT}_{\min }\right)+\mathrm{YT}_{\min }\right) \times(\mathrm{M} / 100)$

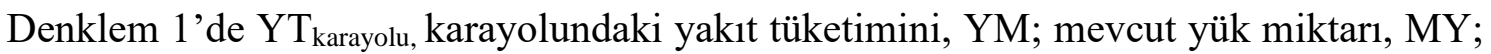
konteynerde taşınabilecek maksimum yük, M; karayolu mesafesi, YT $\max 100$ km'de maksimum yükün taşınmasında tüketilen yakıt miktarını, $\mathrm{YT}_{\min }$ taşıt boş iken 100 km'de tüketilen yakıt miktarını göstermektedir.

\section{Demiryolu yakıt tüketimi}

Demiryolu taşımacılığ için bir lokomotifte 80 adet vagon taşınmakta ve her vagonda bir adet standart konteyner taşınmaktadır. Bir lokomotifin 100 km'de 85-100 litre aralığında dizel yakıt tükettiği kabul edilerek analizlerde en elverişsiz koşullarda hesap yapmak için yakıt tüketimi 100 litre alınarak hesap yapılmaktadır [23]. Demiryolu yakıt tüketimi, Denklem 2'ye göre hesaplanmaktadır.

$Y T_{\text {demiryolu }}=((M / 100) \times O Y T) / K S$

Denklem 2'de demiryolu taşımacılığında yakıt tüketim hesabının denklemi

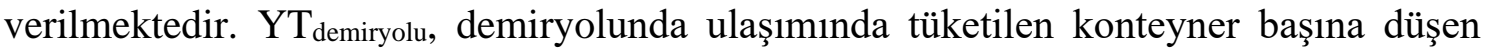
yakıt tüketimini vermektedir. M; demiryolu mesafesi, OYT; bir lokomotifin 100 km'de ortalama yakıt tüketimi; KS ise lokomotifte taşınan konteyner sayısıdır.

\section{Denizyolu yaklt tüketimi}

Denizyolu taşımacılı̆̆ında yakıt tüketimi, limanda ve seyirde ana ve yardımcı makinelerin yakıt tüketimi esas alınarak hesaplanmaktadır. Seyirde ana makine günlük 500 ton fuel oil, yardımc1 makine günlük 30 ton dizel yakıt yakmaktadır. Limanda ise yardımcı makine günlük 45 ton dizel yakıt tüketmektedir [22]. Sürat, konteyner gemileri için 2010 yılı ortalama bir değer olan 25 knots alınmaktadır [24]. Limanda yükün 
yükleme boşaltma süresi 3 gün alınmaktadır [22]. En büyük yük gemilerinin konteyner kapasitesi maksimum 18000 adet konteynerdir [25]. Bu çalışmada yük gemisinde 10000 adet konteyner taşındığı kabul edilmektedir. Denizyolu yakıt tüketimi, Denklem 3'e göre hesaplanmaktadır.

$Y T_{\text {denizyolu }}=\left(S A M_{G Y T} \times S S+S Y M_{G Y T} \times S S+L Y M_{G Y T} \times L B S\right) / K S$

Denizyolu ulaşımında yakıt tüketimi Denklem 3'e göre hesaplanmaktadır. YT $T_{\text {denizyolu, }}$ denizyolu taşımacılığında konteyner başına düşen yakıt tüketimini göstermektedir. $\mathrm{SAM}_{\mathrm{GYT}}$, seyirde ana makine günlük yakıt tüketimini, $\mathrm{SYM}_{\mathrm{GYT}}$, seyirde yardımcı makine günlük yakıt tüketimini göstermektedir. SS ise geminin seyir süresini temsil etmektedir. $\mathrm{LYM}_{\mathrm{GYT}}$, limanda yardımcı makine günlük yakıt tüketimini; LBS, limanda bekleme süresini göstermektedir. KS değeri geminin mevcut taşıdığı konteyner adedini göstermektedir. Tüm makinelerin yaktığı yakıt miktarı taşınan konteyner sayısına bölünerek konteyner başına düşen birim yakıt tüketimi hesaplanmaktadır.

\subsection{Maliyet hesabt}

Lojistikte en önemli rekabet maliyetlerin düşürülmesi ile sağlanabilmektedir. Genellikle taşımacılıkta optimum güzergâhın seçiminde ilk dikkat edilen unsurun maliyet olduğu göze çarpmaktadır [2].

\section{Karayolu maliyet hesabt}

Karayolu maliyet hesabı yapılırken yakıt tüketimi, sürücü ve dolaylı giderler hesaba katılarak maliyet analizi yapılmaktadır. Dizel yakıtın litre fiyatı 2018 yılı akaryakıt firmalarından alınan bilgilere göre 5,1 TL alınarak hesap yapılmaktadır. Sürücü ve diğer giderler $5 \mathrm{TL} /$ ton kabul edilerek hesap yapılmaktadır. Denklem 4 'te karayolu taşımacılığında maliyet hesabının denklemi verilmektedir.

$M_{\text {karayolu }}=Y T_{\text {karayolu }} \times Y F_{\text {dizel }}+S D G \times Y M \times S S$

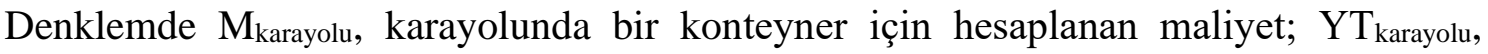

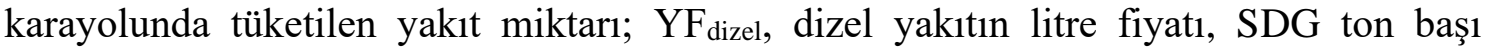
sürücü ve diğer giderleri, SS ise sürücü sayısını göstermektedir. Denklemde YM ise taşınan yükün tonaj değerini vermektedir.

\section{Demiryolu maliyet hesabt}

Demiryolu taşımacılığında maliyet hesabı yapılırken, TCDD'nin İstasyonlar Arası Mesafe ve Taşıma Ücreti Raporundan alınan ton başı birim fiyatlar ve yükün kıymet değeri hesaba katılmaktadır [26]. Demiryolu taşımacılığında maliyet hesabı, Denklem 5'i referans alarak hesaplanmaktadır.

$M_{\text {demiryolu }}=T B F \times Y M+K P$

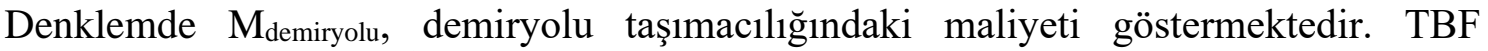
parametresi TCDD'nin İstasyonlar Arası Mesafe ve Taşıma Ücreti Raporu'ndan alınan ton başı birim fiyattır [26]. YM değeri ise konteynerde taşınan yükün tonajıdır. KP değeri, konteynerde taşınan yükün mali değerine göre 1000 km'ye kadar olan demiryolu mesafesinde yükün mali değerinin $1 / 1000$ 'i, $1000 \mathrm{~km}$ den fazla mesafeler için ise 2/1000'sine denk gelen kıymet primine karş1lık gelmektedir.

\section{Denizyolu maliyet hesabı}


Denizyolu maliyet analizi yapılırken yakıt tüketimi, yükleme boşaltma masrafı, terminal hizmeti, limana giriş çıkış ücretleri ele alınmaktadır. Yakıt tüketimi dışında kalan maliyet kalemleri TCDD'nin Liman Hizmetleri Tarifesinden alınan birim fiyatlara göre hesaplanmaktadır [27]. Limanda yükleme boşaltma gideri $352 \mathrm{TL} /$ konteyner, limanda terminal hizmeti kapsamında 137,2 TL/konteyner, yük karayolu ile aktarma yapilıyor ise limana giriş-çıkış ücreti $98 \mathrm{TL} /$ taşıt alınmaktadır. Gemide personel ve diğer giderler ise 6,16 TL/gün/konteyner olarak hesaba katılmaktadır. Ülkemizde denizyolu ulaşımında yük gemilerinde, akaryakıt fiyatlarına uygulanan Özel Tüketim Vergisi (ÖTV) denizyolu taşımacılığı yapan gemilerin akaryakıtlarına uygulanmamaktadır. Bu nedenle denizyolu taşımacılığında fuel oil ve dizel akaryakıt fiyatlarının ÖTV'siz değerleri hesaba katılmaktadır. ÖTV'siz fuel oil 2,56 TL/kg, ÖTV'siz motorin ise 3,45 TL/1 kabul edilerek maliyet hesabı yapılmaktadır. Denizyolu taşımacılığında maliyet hesabı Denklem 6'yı esas alarak yapılmaktadır

$M_{\text {denizyolu }}=\left(Y T_{\text {anamakine }} \times F O F+Y T_{\text {yardimctmakine }} \times D F\right) / K S+Y B+T H+L G C+G E G$

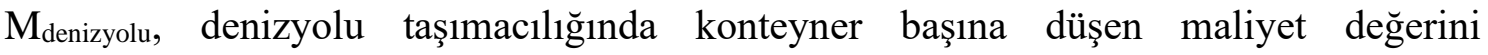

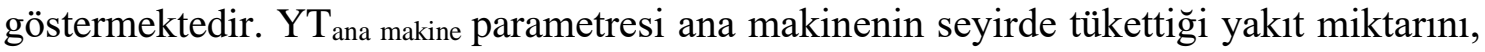

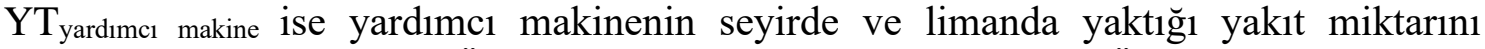
vermektedir. FOF değeri ÖTV'siz fuel oil litre fiyatını, DF ise ÖTV'siz dizel yakıtın litre maliyetini temsil etmektedir. GEG parametresi gemi personeli ve dolayli giderleri göstermektedir. KS, geminin taşıdığı konteyner sayısını; YB, yükleme boşaltma giderlerini; $\mathrm{TH}$, terminal hizmetlerini; LGÇ değeri ise karayolu aktarması var ise karayolu taşıtının limana giriş çıkış ücretini göstermektedir.

\subsection{Taşımacılık Süresi Hesabı}

Ulaştırma süresi, sefer sıklığı, dakiklik müşteriler tarafından dikkate alınan önemli etmenlerdir. Ürünün ortalama teslimat süresi çoğu zaman en önemli nakliye parametresi olarak belirlenmektedir [28]. Bu çalışmada, yükün çıkış biriminden varış birimine kadar geçen süreçte, yükün yükleme boşaltma süresinden, yolda geçen taşıma süresine kadar bütün süreçler, taşımacılık süresi başlığı altında değerlendirilmektedir.

\section{Karayolu taşımacılık süresi hesabı}

Yükleme boşaltma süresi 30 dakika alınmaktadır [22]. Karayolunda taşımacılık süresi hesaplanırken sürücünün her 4,5 saatte 45 dakika mola vermektedir. İkinci 4,5 saat sürüşten sonra 14,25 saat sürücüye dinlenme süresi verilmektedir. Taşıtı en az iki sürücü kullanması halinde her 30 saatlik sürede her bir sürücü en az 8 saat kesintisiz olarak dinlenmektedir [29]. Ortalama hız $80 \mathrm{~km} / \mathrm{sa}$ alınmaktadır [30]. Karayolu yük taşımacılığı için taşımacılık süresi Denklem 7'ye göre hesaplanmaktadır.

$T S_{\text {karayolu }}=M / H+S D S+Y B S$

Karayolu taşımacılık süresi Denklem 7'ye göre hesaplanmaktadır. TS karayolu karayolu taşımacılık süresini göstermektedir. Denklemdeki M parametresi karayolu mesafesini, $\mathrm{H}$ değeri taşıtın ortalama hızını, SDS sürücü dinlenme sürelerini, YBS ise yükleme boşaltma sürecindeki geçen zamanı temsil etmektedir.

\section{Denizyolu taşımacılı süresi hesabı}


Denizyolu taşımacılığında zaman hesaplanırken, yükleme-boşaltma süresi 3 gün alınmaktadır [22]. Geminin sürati yakıt tüketim hesabında da bahsedildiği gibi 25 knot olarak alınmaktadır. Denizyolu yük taşımacılığı için taşımacılık süresi Denklem 8'a göre hesaplanmaktadır.

$T S_{\text {denizyolu }}=M / H+\lambda \times Y B S$

Denizyolu taşımacılık süresi Denklem 8'de verilen formüle göre hesaplanmaktadır.

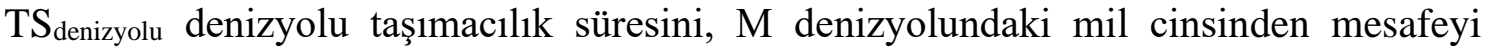
göstermektedir. H parametresi knot biriminde geminin hızını, YBS ise limanda yükleme boşaltma süresini göstermektedir. $\lambda$ katsayısı liman da oluşabilecek operasyonel, iklimsel ve mevcut liman trafiğine göre belirlenen katsayıdır.

\section{Demiryolu taşımacılık süresi hesabı}

Demiryolu taşımacılığında yükleme-boşaltma süresi 22,5 dakika alınmaktadır[2]. Ülkemizde yük trenleri maksimum $70 \mathrm{~km} / \mathrm{sa}$ hıza çıkabilirken, Avrupa ülkelerinde yük trenleri $100 \mathrm{~km} / \mathrm{sa}$ hızın üzerine çıkabilmektedir [31]. Bu sebeple çalışmada yük treninin hızı $70 \mathrm{~km} / \mathrm{sa}$ seçilmektedir. Demiryolu yük taşımacılığı için taşımacılık süresi Denklem 9'a göre hesaplanmaktadır.

$T S_{\text {demiryolu }}=M / H+\alpha \times Y B S$

Demiryolu taşımacılık süresi Denklem 9'a göre hesaplanmaktadır. Denklemde $\mathrm{TS}_{\text {demiryolu }}$ demiryolu taşımacılık süresini vermektedir. $\mathrm{M}$ değişkeni demiryolu taşımacılığında kat edilen mesafeyi $\mathrm{km}$ cinsinden göstermektedir. H parametresi trenin ortalama hızını, YBS ise bir konteyner için yükleme-boşaltma süresini vermektedir. $\alpha$ demiryolu yük taşımacılığında yük treninde taşınan konteyner sayısı demiryolu güzergâhının başlangıç ve bitiş noktası arasındaki ara durak sayısından fazla ise ara durak sayısına, değil ise konteyner sayısına eşit alınmaktadır. $\alpha$ parametresi ile ara duraklarda bekleme ve yükleme boşaltma sürelerinden kaynaklı gecikmeler demiryolu taşımacılık süresine eklenmektedir.

\subsection{Emisyon hesabı}

Ülkemizde, ulaştırma sektörünün, tüm sektörlere göre sera gazı emisyonu payı \%5,63 oranına sahiptir [32]. Bu çalışmada ekonomik, hızlı güzergâh anlayışının yanı sıra çevreci güzergâh anlayışı da ön plana çıkarılmaktadır. Ulaşım türlerine bağlı olarak emisyon miktarı karayolu, demiryolu için Denklem 10'a göre hesaplanmaktadır [33].

$E=Y M \times D \times E F$

Denklemde E, gram cinsinden $\mathrm{CO}_{2}$ salınım miktarını vermektedir. YM taşınan yük miktarını, D taşıma mesafesini ve $\mathrm{EF}$ ise ton başı $\mathrm{CO}_{2}$ emisyon faktörünü göstermektedir. EF'nin hesabı ise Denklem 11'de verilmektedir.

$E F=T \times M \times e /(1000000)$

Denklemde T yük miktarı, $\mathrm{M}$ mesafe, e ise ton-km başı gram cinsinden $\mathrm{CO}_{2}$ emisyon miktarını vermektedir. Denizyolu taşımacılığında emisyon miktarı Denklem 12'ye göre hesaplanmaktadır [22]. 
Denklemde $\mathrm{T}$ çalışma türünde (seyir veya manevra) geminin bulunduğu zaman, $\mathrm{P}$ geminin çalışma türünde kullandığı makinelerin güçleri, EF gemi türü ve emisyon türüne göre emisyon çarpanıdır. MY çarpanı ise makinelerin ilgili çalışma türündeki yüzde makine gücüdür. Geminin ana makine gücü $1610 \mathrm{~kW}$, yardımcı makine gücü ise $165 \mathrm{~kW}$ alınmaktadır. Jeneratörlerin gücü ise $47 \mathrm{~kW}$ alınmaktadır. Ana Makine yükü gemi seyir halindeyken $\% 80$, manevrada iken ise \%40'tır [22]. Geminin manevra süresi 2 saat (0,083 gün) kabul edilmektedir.

\subsection{Genelleştirilmiş maliyet}

Ulaştırma modunun seçim kriterleri, büyük ölçüde yük türüne bağlıdır [v]. Örneğin zaman, değer / kg oranı yüksek olan ve kısa yaşam döngüleri olan ürünler için diğer seçim kriterlerine göre daha önemli bir kriterdir. Ulaştırma ekonomisinde bir seyahatin parasal ve parasal olmayan maliyetlerin toplamı genelleştirilmiş maliyet olarak tanımlanmaktadır [34]. Çalışmada, rotaların birbirleri ile karşılaştırılmasında bütün parametrelerin etkili bir şekilde kullanılması için genelleştirilmiş maliyet hesabı da yapılmaktadır. Genelleştirilmiş maliyet hesaplanması için öncelikle bütün parametreler kendi içlerinde normalize edilmektedir (Denklem 13). Normalize edildikten sonra değerler toplanıp ortalaması alınarak genelleştirilmiş maliyete ulaşılmaktadır (Denklem 14).

$X_{N}=\left(X_{\max }-X\right) /\left(X_{\max }-X_{\min }\right)$

Denklem 13'te $X_{N}$ değeri sayının normalizasyon değerini gösterirken, $X_{\max }$ değerler içerisindeki maksimumu, $X_{\min }$ değerler içerisindeki minimum değeri ve $X$ değeri normalize edilmek istenen veriyi temsil etmektedir.

$G M=\left(Y T_{N}+M_{N}+T S_{N}+E_{N}\right) / 4$

Denklem 14'te GM değeri genelleştirilmiş maliyete karşıllı gelirken, $\mathrm{YT}_{\mathrm{N}}$ normalize edilmiş yakıt değerini, $\mathrm{M}_{\mathrm{N}}$ normalize edilmiş maliyeti, $\mathrm{TS}_{\mathrm{N}}$ normalize edilmiş taşımacılık süresini ve $E_{N}$ normalize edilmiş emisyon değerini göstermektedir.

\section{Bulgular ve tartışma}

Hatay'da ihracat potansiyeli yüksek olan filtre malzemesi yükü esas alınmaktadır. Yükün standart $40^{\prime}$ ' konteyner ile taşındığı kabul edilmektedir. Filtre fabrikasından alınan bilgilere göre 5, 10 ve 14 ton yük birimleri seçilmektedir. Trakya bölgesinde Çorlu sanayisine hakim olan Tekirdağ iline yük taşımacılığı yapılmaktadır. Vaka analizi olarak Tekirdağ'ın seçilmesinin nedeni çok türlü taşımacılık uygulamalarının yapılabilme potansiyelinin yüksek olmasından kaynaklıdır. Tablo 1'de oluşturulan rotaların mod değişim noktaları verilmektedir. 
Tablo 1. Hatay ve Tekirdağ arasındaki taşımacılık rotaları ve mod değişim noktaları.

\begin{tabular}{|c|c|c|c|c|c|c|c|}
\hline Ulaşım Rotası & $\begin{array}{l}\text { Başlangıç } \\
\text { Noktası }\end{array}$ & $\begin{array}{l}\text { 1. Ulaşım } \\
\text { Modu }\end{array}$ & $\begin{array}{l}\text { 1. Mod } \\
\text { Değişim } \\
\text { Noktası }\end{array}$ & $\begin{array}{l}\text { 2. Ulaşım } \\
\text { Modu }\end{array}$ & $\begin{array}{l}\text { 2. Mod } \\
\text { Değişim } \\
\text { Noktası }\end{array}$ & $\begin{array}{l}\text { 3. Ulaşım } \\
\text { Modu }\end{array}$ & $\begin{array}{l}\text { Varış } \\
\text { Noktası }\end{array}$ \\
\hline Unimodal Karayolu & \multirow{7}{*}{ Hatay } & Karayolu & - & - & - & - & \multirow{7}{*}{ Tekirdağ } \\
\hline Unimodal Denizyolu & & Denizyolu & - & - & - & - & \\
\hline Unimodal Demiryolu & & Demiryolu & - & - & - & - & \\
\hline Multimodal 1 & & Denizyolu & Antalya & Karayolu & Isparta & Demiryolu & \\
\hline Multimodal 2 & & Demiryolu & Balıkesir & Denizyolu & - & - & \\
\hline Multimodal 3 & & Demiryolu & Samsun & Denizyolu & - & - & \\
\hline Multimodal 4 & & Demiryolu & İzmit & Denizyolu & - & - & \\
\hline
\end{tabular}

Hatay-Tekirdağ arasında oluşturulan rotaların ulaşım türlerine göre mesafe dağılımları Tablo 2'de verilmektedir.

Tablo 2. Hatay ve Tekirdağ arasındaki taşımacılık rotalarının türlere göre mesafe değerleri.

\begin{tabular}{lrrr}
\hline Ulaşım Rotası & \multicolumn{3}{c}{ Mesafe } \\
\hline & Karayolu(km) & Denizyolumil) & Demiryolu (km) \\
\cline { 2 - 4 } Unimodal Karayolu & 1164 & - & - \\
Unimodal Denizyolu & 47,3 & 827,37 & - \\
Unimodal Demiryolu & 15,7 & - & 1215 \\
Multimodal 1 & 152,8 & 290 & 618 \\
Multimodal 2 & 49,20 & 52,52 & 1228 \\
Multimodal 3 & 49,20 & 466,75 & 1019 \\
Multimodal 4 & 49,20 & 115,04 & 1157 \\
\hline
\end{tabular}

Oluşturulan rotaların yakıt tüketimi, maliyet, taşıma süresi ve emisyon değerleri materyal metotta belirtilen kabuller dikkate alınarak hesaplanmaktadır. Bulunan sonuçlara göre rotalar arası karşılaştırmalar yapılmaktadır. Bu amaçla hem yakıt tüketimi, hem maliyet, hem taşıma süresi, hem de emisyon değerlerini ayrı ayrı değerlendirmenin yanı sıra bunların etkili olduğu genelleştirilmiş maliyet karşılaştırması yapilmaktadir.

\subsection{Yakıt tüketimi hesabı}

\section{Hatay-Tekirdăg arası unimodal karayolu için;}

Karayolu taşımacılığında yakıt tüketimini yükün ağırlığı etkilediği için hesaplar üç farklı yük tonajı için yapılmaktadır. Denklem 1'e göre Hatay-Tekirdağ arasında karayolu taşımacılığında yakıt tüketimi aşağıdaki gibi hesaplanmaktadır.

5 ton yük taşınmasında;

$\mathrm{YT}_{\text {karayolu }}=\left((\mathrm{YM}) /(\mathrm{MY}) \times\left(\mathrm{YT}_{\max }-\mathrm{YT}_{\min }\right)+\mathrm{YT}_{\min }\right) \times(\mathrm{M} / 100)$

$=(1164 / 100) \times((5 / 26) \times(40-30)+30)=371,59$ lt dizel

10 ton yük taşınmasında;

$\mathrm{YT}_{\text {karayolu }}=\left((\mathrm{YM}) /(\mathrm{MY}) \times\left(\mathrm{YT}_{\max }-\mathrm{YT}_{\min }\right)+\mathrm{YT}_{\min }\right) \times(\mathrm{M} / 100)$

$=(1164 / 100) \times((10 / 26) \times(40-30)+30)=393,97 \mathrm{lt}$ dizel

14 ton yük taşınmasında;

$\mathrm{YT}_{\text {karayolu }}=\left((\mathrm{YM}) /(\mathrm{MY}) \times\left(\mathrm{YT}_{\max }-\mathrm{YT}_{\min }\right)+\mathrm{YT}_{\min }\right) \times(\mathrm{M} / 100)+(\mathrm{M} / 100) \times \mathrm{YT}_{\min }$ $=(1164 / 100) \times((14 / 26) \times(40-30)+30)=411,88$ lt dizel 
5 ton yük taşınırken taşıt 371,59 1t, 10 ton yük taşınırken 393,97 lt, 14 ton yük taşınırken 411,88 lt dizel yakıt tüketmektedir. Yük ağırlığının 5 tondan 10 tona çıkması ile yakıt tüketiminde $\% 6$ artış gözlenmektedir. 14 ton taşınması için taşıtın yakıt tüketimi 5 tona kıyasla \% 10,8 artmaktadır.

Hatay-Tekirdăg arası unimodal denizyolu için;

Hatay ve Tekirdağ arasında denizyolu taşımacılığı için yakıt tüketimi hesaplanırken öncelikle geminin seyir süresi belirlenmektedir.

Seyir Süresi $=$ mesafe $/$ hız $=(827,37 / 25) / 24=1,38$ gün

Seyirde Yakıt Tüketimi;

Ana makine; $500 \times 1,38=690$ ton fuel oil

Yardımc1 makine; $30 \times 1,38=41,4$ lt dizel

Limanda Yakıt Tüketimi $=45 \times 3=135$ lt dizel

$\mathrm{YT}_{\text {denizyolu }}=\left(\mathrm{SAM}_{\mathrm{GYT}} \times \mathrm{SS}+\mathrm{SY} \mathrm{M}_{\mathrm{GYT}} \times \mathrm{SS}+\mathrm{LY} \mathrm{M}_{\mathrm{GYT}} \times \mathrm{LBS}\right) / \mathrm{KS}=(690 * 1000+41,4+135) / 10$

$000=69,02 \mathrm{lt} /$ konteyner

Denizyolu taşımacılığında yakıt tüketimi 69,02 1t/konteyner hesaplanmaktadır. Görüldüğü gibi bir konteynerin karayolunda taşınması ile bir konteynerin denizyolunda taşınması karşılaştırıldığında yakıt tüketiminde oldukça fark oluşmaktadır.

\section{Hatay-Tekirdăg arası unimodal demiryolu için;}

Hatay-Tekirdağ arasındaki demiryolu taşımacılığı için yakıt tüketimi Denklem 3'e göre aşağıdaki gibi hesaplanmaktadır.

Konteyner başı yakıt tüketimi;

$\mathrm{YT}_{\text {demiryolu }}=((\mathrm{M} / 100) \times \mathrm{OYT}) / \mathrm{KS}=[(1215 / 100) \times 100] / 80=15,191 \mathrm{t} /$ konteyner dizel

Demiryolu taşımacılığında 15,19 1t/konteyner dizel yakıt yaktığı hesaplanmaktadır. Diğer unimodal ulaşım türleri ile karşılaştırıldığında yakıt tüketimi bakımından karayolu taşımacılığına ve denizyolu taşımacılığına kıyasla daha avantajlı çıkmaktadır. Tabi ki ulaşım coğrafyasının bunun üzerinde önemli bir etkisi vardır.

Hatay ve Tekirdağ arasında yapılan taşımacılık türlerine göre yakıt tüketim grafiği Şekil 1 'de verilmektedir. Grafikte karayolu ile yapılan yük taşımacılığında diğer ulaşım türlerine kıyasla açık ara fazla yakıt tüketildiği görülmektedir. En az yakıt tüketimi ise 20,19-20,74 lt yakıt tüketim aralığı ile demiryolu rotasında hesaplanmaktadır. Multimodal 2 ve multimodal 3 rotalarında unimodal denizyolu ve karayolu taşımacılığından daha az yakıt tüketiminin gerçekleştiği dikkat çekmektedir. Yük tonajının artışı ulaşım türleri içerisinde yakıt tüketiminde çok fark yaratmamaktadır. 


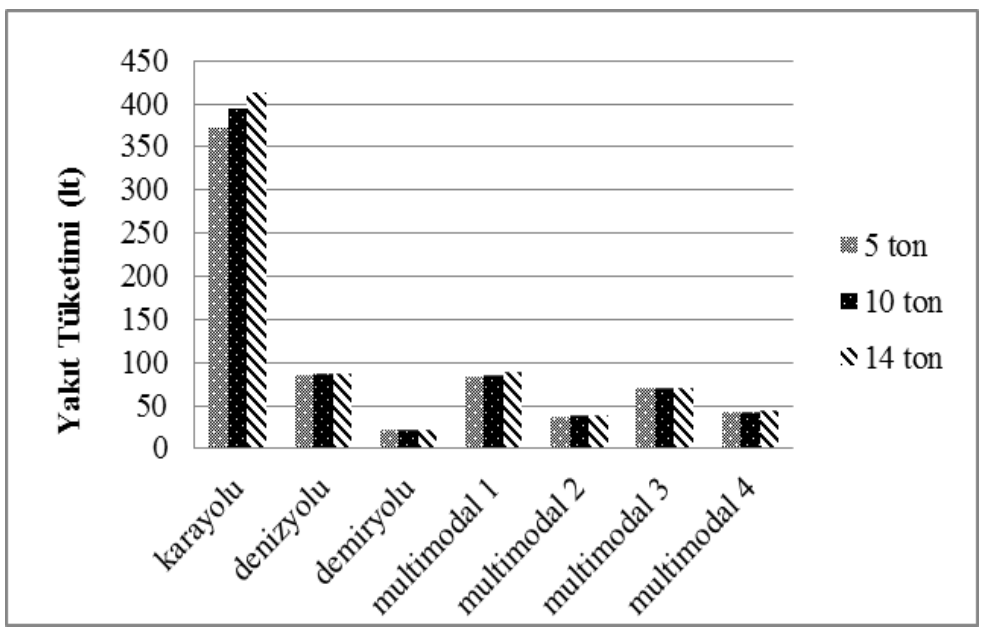

Şekil 1. Hatay-Tekirdağ arası ulaşım rotalarına göre yakıt tüketim miktarları.

\subsection{Maliyet hesabı}

\section{Hatay-Tekirdăg arası unimodal karayolu için;}

Hatay'dan Tekirdağ'a yapılacak olan konteyner yük taşımacılı̆̆ 1 için karayolu maliyet hesabı aşağıdaki gibi yapılmaktadır. Karayolu taşımacılığında yükün ağırlığı, maliyeti belirleyen önemli parametrelerden birisidir. Bundan dolayı yük arttıkça maliyette de artış gözlenmektedir.

5 ton yük taşınmasında;

$\mathrm{M}_{\text {karayolu }}=\mathrm{YT}_{\text {karayolu }} \times \mathrm{YF}_{\text {dizel }}+\mathrm{SDG} \times \mathrm{YM} \times \mathrm{SS}=371,59 \mathrm{lt} \times 5,1 \mathrm{TL} / \mathrm{t}+5 \mathrm{t} \times 5 \mathrm{TL} / \mathrm{t} \times 1=1920,11$

$\mathrm{TL}$

10 ton yük taşınmasında;

$\mathrm{M}_{\text {karayolu }}=\mathrm{YT}_{\text {karayolu }} \times \mathrm{YF}_{\text {dizel }}+\mathrm{SDG} \times \mathrm{YM} \times \mathrm{SS}=393,97 \mathrm{lt} \times 5,1 \mathrm{TL} / \mathrm{lt}+10 \mathrm{t} \times 5 \mathrm{TL} / \mathrm{t} \times 1=2059,25$ TL

14 ton yük taşınmasında;

$\mathrm{M}_{\text {karayolu }}=\mathrm{YT}_{\text {karayolu }} \times \mathrm{YF}_{\text {dizel }}+\mathrm{SDG} \times \mathrm{YM} \times \mathrm{SS}=411,88 \mathrm{lt} \times 5,1 \mathrm{TL} / \mathrm{lt}+14 \mathrm{t} \times 5 \mathrm{TL} / \mathrm{t} \times 1=2170,59$ $\mathrm{TL}$

Yük tonajının 5 tondan 10 tona çıkartılması ile birlikte maliyette $\% 7,30$, yükün 14 tona çıkması ile \%13,05 artış görülmektedir.

\section{Hatay-Tekirdă arası unimodal denizyolu için;}

Denizyolu taşımacılığında konteynerin ağırlığı hesaba katılmamakta, konteyner adedi üzerinden hesap yapılmaktadır. Aşağıda Hatay'dan Tekirdağ'a denizyolu ile giden bir yük için konteyner başı maliyet hesabı verilmektedir.

$\mathrm{M}_{\text {denizyolu }}=\left(\mathrm{YT}_{\text {anamakine }} \times \mathrm{FOF}+\mathrm{YT}_{\text {yardmmcımakine }} \times \mathrm{DF}\right) / \mathrm{KS}+\mathrm{YB}+\mathrm{TH}+\mathrm{LGÇ}+\mathrm{GEG}=(690 * 1000$ $1 \mathrm{t} \times 2,56 \mathrm{TL} / \mathrm{t}+176,4 \quad \mathrm{tt} \times 3,45 \mathrm{TL} / \mathrm{lt}) / 10000+352 \mathrm{TL}+137,2 \quad \mathrm{TL}+98 \mathrm{TL}+6,16 \mathrm{TL} /$ gün $\times(1,23+3)$ gün= 789,96 TL/konteyner

Denizyolu taşımacılığında maliyeti etkileyen en önemli parametreler, limanda alınan hizmetlerden oluşmaktadır. Karayolu taşımacılığı ile karşılaştırıldığında denizyolu taşımacılığ i ile yaklaşık 2,74 kat maliyette tasarruf sağlanmaktadır. 


\section{Hatay-Tekirdăg arası unimodal demiryolu için;}

Aşağıda Hatay ve Tekirdağ arasında yapılacak demiryolu konteyner yük taşımacılı̆̆ının farklı yük tonajı ve yük değerlerine bağlı olarak maliyet hesabı verilmektedir. TCDD'nin İstasyonlar Arası Mesafe ve Taşıma Ücreti Raporundan alınan ton başı birim fiyat tarifesine göre bu iki nokta arası maliyet 108,50 TL/t hesaplanmaktadır. Bu iki nokta arası $1215 \mathrm{~km}$ olarak bulunmakta ve mesafe $1000 \mathrm{~km}$ den fazla olduğu için kıymet primi yükün değerinin 2/1000'si alınmaktadır.

5 ton yük için;

$\mathrm{M}_{\text {demiryolu }}=\mathrm{TBF} \times \mathrm{YM}+\mathrm{KP}=108,50 \mathrm{TL} / \mathrm{t} \times 5 \mathrm{t}+40000 \mathrm{TL} \times 2 / 1000=622,5 \mathrm{TL}$

10 ton yük için;

$\mathrm{M}_{\text {demiryolu }}=\mathrm{TBF} \times \mathrm{YM}+\mathrm{KP}=108,50 \mathrm{TL} / \mathrm{t} \times 10 \mathrm{t}+145000 \mathrm{TL} \times 2 / 1000=1375 \mathrm{TL}$

14 ton yük için;

$\mathrm{M}_{\text {demiryolu }}=\mathrm{TBF} \times \mathrm{YM}+\mathrm{KP}=108,50 \mathrm{TL} / \mathrm{t} \times 14 \mathrm{t}+250000 \mathrm{TL} \times 2 / 1000=2019 \mathrm{TL}$

Yükün 5 tondan 10 tona çıkması ve mali değerin 40.000 TL'den 145.000 TL'ye çıkması ile taşıma maliyeti \%121 artmaktadır. Yük tonaj1 14 ton ve mali değeri $250.000 \mathrm{TL}$ olması ile maliyet \%224 artmaktadır. Burada görüldüğü gibi demiryollarında yükün kıymet değeri, maliyeti önemli ölçüde etkilemektedir. Şekil 2'de ulaşım modlarına ve yük tonajına göre maliyet analizi verileri görülmektedir. Grafik incelendiğinde denizyolu ulaşım türünün diğer türlere göre en ucuz taşımacılık olduğu açıkça görülmektedir. En maliyetli taşımacılık ise üç yük birimi içinde karayolu taşımacılığıdır. Demiryolu taşımacılığı yük tonajı ve değeri arttıkça taşımacılık maliyetleri ciddi oranda etkilenmektedir. Multimodal taşımacılığın 5 ve 10 ton yük birimleri için karayoluna kıyasla daha ucuz taşımacılık türü olduğu göze çarpmaktadır. Güzergâh kombinasyonları içerisinde bulunan demiryolu ve denizyolu taşımacılığ oranına göre yük birimi arttıkça maliyetlerdeki artışta buna göre artış göstermektedir.

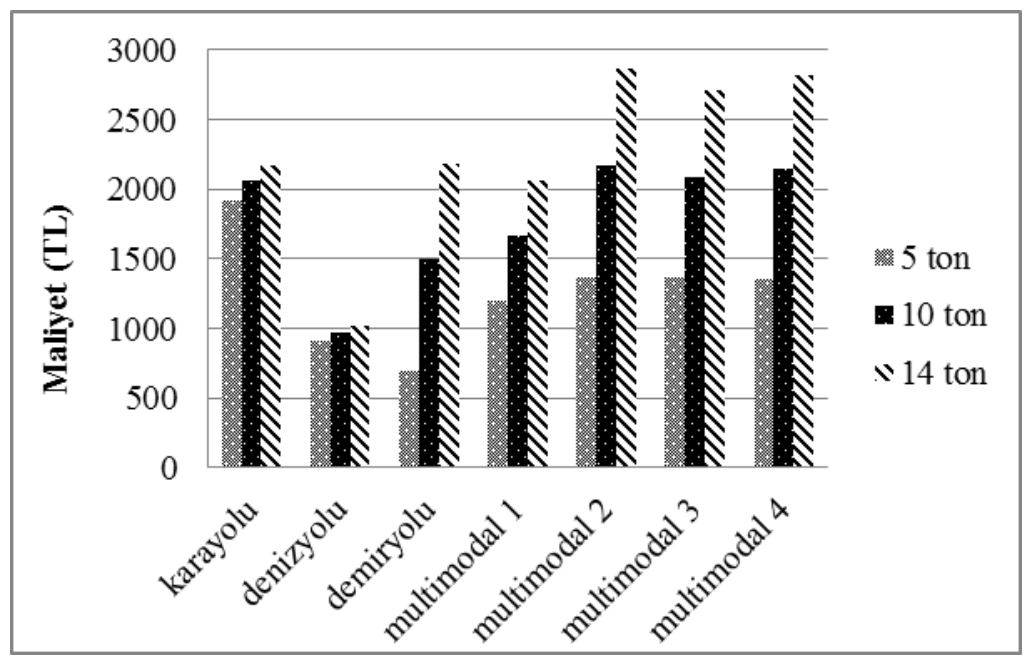

Şekil 2. Hatay-Tekirdağ arası ulaşım rotalarına göre maliyet değerleri.

\subsection{Taşımacılık süresi hesabı}

Her güzergâh için materyal metotta verilen taşımacılık süresi formülleri kullanılarak zaman hesapları aşağıda yapılmaktadır. Karayolu taşımacılık ayağında yükün tek 
sürücülü olarak taşındığı kabulü yapılarak hesap yapılmaktadır. Demiryolu taşımacılığında ara durak sayısı 87 ve taşınan konteyner sayısı 80 adet olduğu için $\alpha$ değeri taşınan konteyner sayısına eşit alınmaktadır. Denizyolu taşımacılık süresi hesabında limanda mevsimsel ve operasyonel gecikmelerin yaşanmadığı kabul edilerek $\lambda$ değeri 1 alınmaktadır. Yük tonajına bağlı olarak taşımacılık süreleri değişmemektedir.

Hatay-Tekirdağ arası Unimodal Karayolu için;

$\mathrm{TS}_{\text {karayolu }}=\mathrm{M} / \mathrm{H}+\mathrm{SDS}+\mathrm{YBS}=(1164 \mathrm{~km}) /(80 \mathrm{~km} / \mathrm{sa})+45 \mathrm{dk}+30 \mathrm{dk}+14,25 \mathrm{sa}=30,05 \mathrm{sa}$

Hatay-Tekirdağ arası Unimodal Denizyolu için;

$\mathrm{TS}_{\text {denizyolu }}=\mathrm{M} / \mathrm{H}+\lambda \times \mathrm{YBS}=(827,37 \mathrm{mil}) /(25 \mathrm{knots})+1 \times 3$ gün $\times 24 \mathrm{sa}=105,10 \mathrm{sa}$

Hatay-Tekirdağ arası Unimodal Demiryolu için;

$\mathrm{TS}_{\text {demiryolu }}=\mathrm{M} / \mathrm{H}+\alpha \times \mathrm{YBS}=(1215 \mathrm{~km}) /(70 \mathrm{~km} / \mathrm{sa})+80 \times 22,5 \mathrm{dk}=47,36 \mathrm{sa}$

Hatay-Tekirdağ arasında tasarlanan güzergâh senaryolarının taşımacılık süreleri değerleri Şekil 3'te karşılaştırılmaktadır. En hızlı taşımacılık güzergâhı 30,05 sa ile karayoludur. Lojistik operasyon süreçlerinden kaynaklı olarak en verimsiz taşımacılık rotaları multimodal ve denizyoludur. Karayolu taşımacılığı ile karşılaştıııldığında 4 kata varan bir taşımacılık süre artışı görülmektedir. Bozulabilir yükler için ve hızlı nakliyenin gerektiği yükler için multimodal ve denizyolu taşımacılığının elverişsiz olduğu görülmektedir.

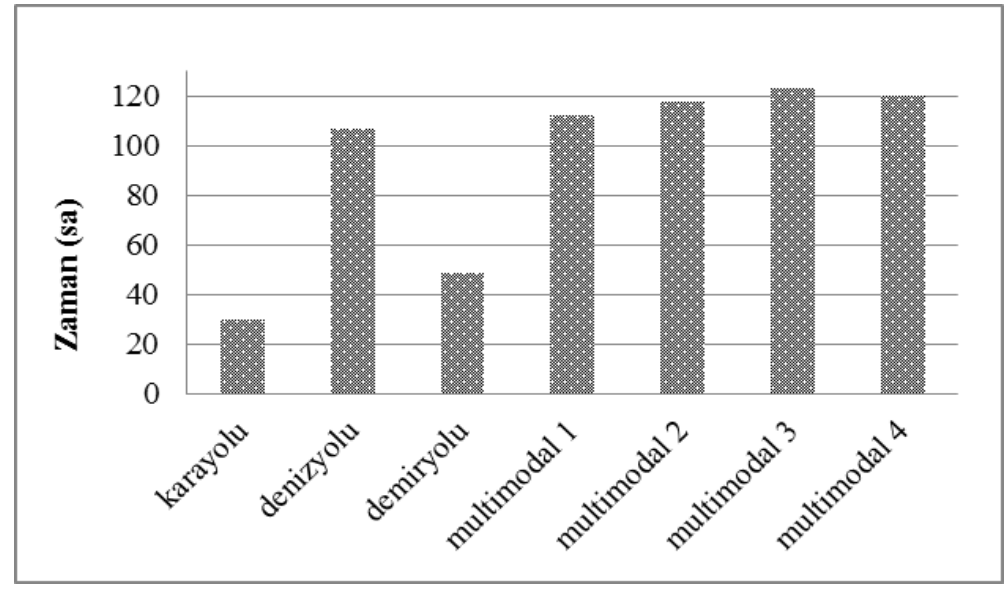

Şekil 3. Hatay-Tekirdağ arası ulaşım rotalarına göre taşımacılık süresi dağılımları.

\subsection{Emisyon hesabı}

Hatay ve Tekirdağ arasında gerçekleştirilen güzergahlardan unimodal taşımacılıklara ait emisyon hesapları aşağıdaki gibi yapılmaktadır. Emisyon hesabında karayolu ve demiryolu taşımacılığında yükün tonajı dikkate alınırken, denizyolu taşımacılığında gemide çalışan makine türlerine bağlı olarak emisyon hesabı yapılmaktadır.

Hatay-Tekirdağ arası unimodal karayolu taşımacılığı için emisyon hesabı;

5 ton yük için;

$\mathrm{EF}=\mathrm{T} \times \mathrm{M} \times \mathrm{e} /(1000000)=5 \mathrm{t} \times 1164 \mathrm{~km} \times 151,1 / 1000000=0,879 \mathrm{grt}-\mathrm{km}$

$\mathrm{E}=\mathrm{YM} \times \mathrm{D} \times \mathrm{EF}=5 \mathrm{t} \times 1164 \mathrm{~km} \times 0,879 \mathrm{gr} / \mathrm{t}-\mathrm{km}=5115,78 \mathrm{gr}$ 
10 ton yük için;

$\mathrm{EF}=\mathrm{T} \times \mathrm{M} \times \mathrm{e} /(1000000)=10 \mathrm{t} \times 1164 \mathrm{~km} \times 151,1 / 1000000=1,759 \mathrm{gr} / \mathrm{t}-\mathrm{km}$

$\mathrm{E}=\mathrm{YM} \times \mathrm{D} \times \mathrm{EF}=10 \mathrm{t} \times 1164 \mathrm{~km} \times 1,759 \mathrm{gr} / \mathrm{t}-\mathrm{km}=20474,76 \mathrm{gr}$

14 ton yük için;

$\mathrm{EF}=\mathrm{T} \times \mathrm{M} \times \mathrm{e} /(1000000)=14 \mathrm{t} \times 1164 \mathrm{~km} \times 111,8 / 1000000=1,822 \mathrm{gr} / \mathrm{t}-\mathrm{km}$

$\mathrm{E}=\mathrm{YM} \times \mathrm{D} \times \mathrm{EF}=14 \mathrm{t} \times 1164 \mathrm{~km} \times 1,822 \mathrm{gr} / \mathrm{t}-\mathrm{km}=29691,31 \mathrm{gr}$

Hatay-Tekirdağ arası unimodal demiryolu taşımacılığ 1 için emisyon hesabı;

5 ton yük için;

$\mathrm{EF}=\mathrm{T} \times \mathrm{M} \times \mathrm{e} /(1000000)=5 \mathrm{t} \times 1215 \mathrm{~km} \times 22 / 1000000=0,134 \mathrm{gr} / \mathrm{t}-\mathrm{km}$

$\mathrm{E}=\mathrm{YM} \times \mathrm{D} \times \mathrm{EF}=5 \mathrm{t} \times 1215 \mathrm{~km} \times 0,134 \mathrm{gr} / \mathrm{t}-\mathrm{km}=814,05 \mathrm{gr}$

10 ton yük için;

$\mathrm{EF}=\mathrm{T} \times \mathrm{M} \times \mathrm{e} /(1000000)=10 \mathrm{t} \times 1215 \mathrm{~km} \times 22 / 1000000=0,267 \mathrm{gr} / \mathrm{t}-\mathrm{km}$

$\mathrm{E}=\mathrm{YM} \times \mathrm{D} \times \mathrm{EF}=10 \mathrm{t} \times 1215 \mathrm{~km} \times 0,267 \mathrm{gr} / \mathrm{t}-\mathrm{km}=3244,05 \mathrm{gr}$

14 ton yük için;

$\mathrm{EF}=\mathrm{T} \times \mathrm{M} \times \mathrm{e} /(1000000)=14 \mathrm{t} \times 1215 \mathrm{~km} \times 22 / 1000000=0,374 \mathrm{gr} / \mathrm{t}-\mathrm{km}$

$\mathrm{E}=\mathrm{YM} \times \mathrm{D} \times \mathrm{EF}=14 \mathrm{t} \times 1215 \mathrm{~km} \times 0,374 \mathrm{gr} / \mathrm{t}-\mathrm{km}=6361,74 \mathrm{gr}$

Hatay-Tekirdağ arası unimodal denizyolu taşımacılığı için emisyon hesabı;

Seyirde Emisyon Miktar1;

Ana makine; $\mathrm{E}=\mathrm{T} \times \mathrm{P} \times \mathrm{EF} \times \mathrm{MY}=1,38 \mathrm{gün} \times 1610 \mathrm{~kW} \times 672 \times 0,80=1194439,68 \mathrm{~g} / \mathrm{sefer}$

Yardımcı makine; $\mathrm{E}=\mathrm{T} \times \mathrm{P} \times \mathrm{EF} \times \mathrm{MY}=1,38 \mathrm{gün} \times 165 \mathrm{~kW} \times 672 \times 0,80=122411,52 \mathrm{~g} / \mathrm{sefer}$

$\mathrm{E}_{\text {seyir }}=1194439,68+122411,52=1316851,2 \mathrm{~g} / \mathrm{sefer}$

Manevrada Emisyon Miktar1;

Ana makine; $\mathrm{E}=\mathrm{T} \times \mathrm{P} \times \mathrm{EF} \times \mathrm{MY}=1 / 12$ gün $\times 1610 \mathrm{~kW} \times 730 \times 0,40=39176,67 \mathrm{~g} / \mathrm{manevra}$

Yardımcı makine; $\mathrm{E}=\mathrm{T} \times \mathrm{P} \times \mathrm{EF} \times \mathrm{MY}=1 / 12$ gün $\times 165 \mathrm{~kW} \times 730 \times 0,80=8030 \mathrm{~g} / \mathrm{manevra}$

$\mathrm{E}_{\text {manevra }}=39176,67+8030=47206,67 \mathrm{~g} / \mathrm{manevra}$

Jeneratör için Emisyon Miktar1;

Jeneratörler; $\mathrm{E}_{\text {jeneratör }}=\mathrm{T} \times \mathrm{P} \times \mathrm{EF} \times \mathrm{MY}=4,38$ gün $\times 47 \mathrm{~kW} \times 672 \times 0,80=110670 \mathrm{~g} / \mathrm{liman}$

Denizyolunda Toplam Emisyon Miktarı;

$\mathrm{E}_{\text {deniz }(\mathrm{gemi})}=\mathrm{E}_{\text {seyir }}+\mathrm{E}_{\text {manevra }}+\mathrm{E}_{\text {liman }}=1316851,2+47017,84+110670=1474539,38 \mathrm{~g} / \mathrm{gemi}$

$\mathrm{E}_{\text {deniz }(\text { konteyner })}=1474539,38 / 10000=147,45 \mathrm{~g} /$ konteyner

Şekil 4'te ulaşım modları ve taşınan yükün ağırlığına bağlı olarak hesaplanan emisyon miktarları verilmektedir. Grafik incelendiğinde minimum emisyon miktarı unimodal denizyolu taşımacılığında görülmektedir. En fazla $\mathrm{CO}_{2}$ salınımı ise 29691,31gr ile 14 ton yükün karayolu ile taşınmasında gerçekleşmektedir. Multimodall taşımacılık güzergahı incelendiğinde, karayolu taşımacılığına ve demiryolu taşımacılığına kıyasla daha az emisyon salınımı hesaplanmaktadır. Bunun nedeni ise multimodal taşımacılık güzergâhının ağırlıklı denizyolu taşımacılığından oluşmasından kaynaklanmaktadır. Ülkemizde yurtiçi yük taşımacılığında ağırlıklı karayolunun tercih edilmesinden dolayı, taşımacılıktan kaynaklanan emisyon değerleri oldukça yüksek çıkmaktadır. 
Taşımacılığın denizyoluna kaydırılması $\mathrm{CO}_{2}$ salınımının indirgenmesinde oldukça etkili olacağı açık bir şekilde görülmektedir.

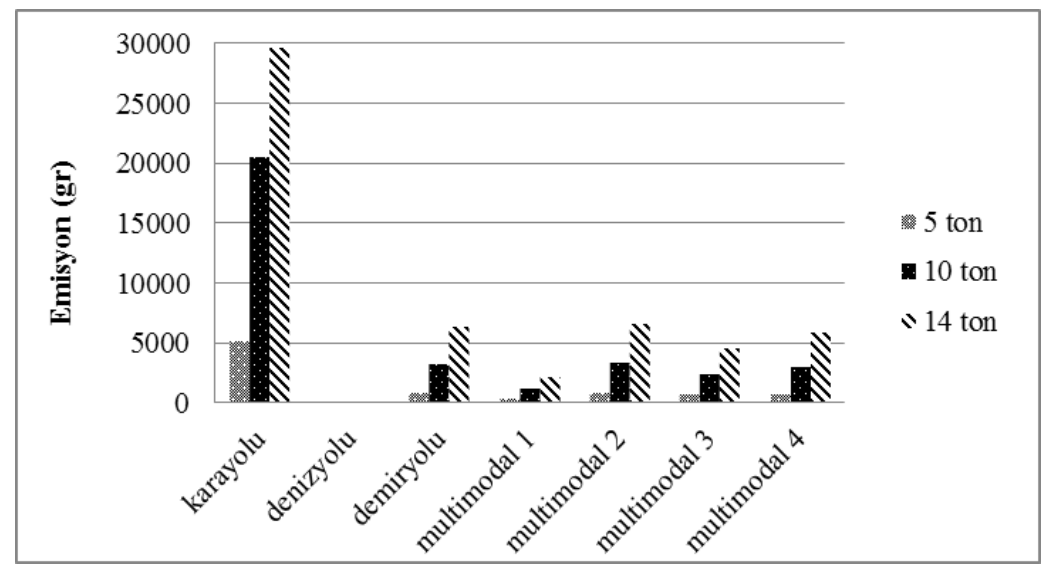

Şekil 4. Hatay-Tekirdağ arası ulaşım rotalarına göre emisyon miktarları.

\subsection{Genelleştirilmiş maliyet}

İskenderun ve Tekirdağ arasındaki rotaların genelleştirilmiş maliyet değerleri Şekil 5 'deki grafikte görülmektedir. Grafiğe göre performansı en yüksek güzergâh 5, 10, 14 ton için sirasiyla \%94,35, \%82,99 ve \%72,43 performans ile unimodal demiryolu taşımacılık güzergâhı en verimli çıkmaktadır. En verimsiz güzergâh ise grafikte görüldüğü gibi tüm yük birimleri için unimodal karayolu taşımacılık rotasıdır. Yük değeri ve ağırlığının artışı karayolu, demiryolu ve multimodal taşımacılık türlerini önemli ölçüde etkileyerek genelleştirilmiş maliyet grafiğine yansımaktadır.

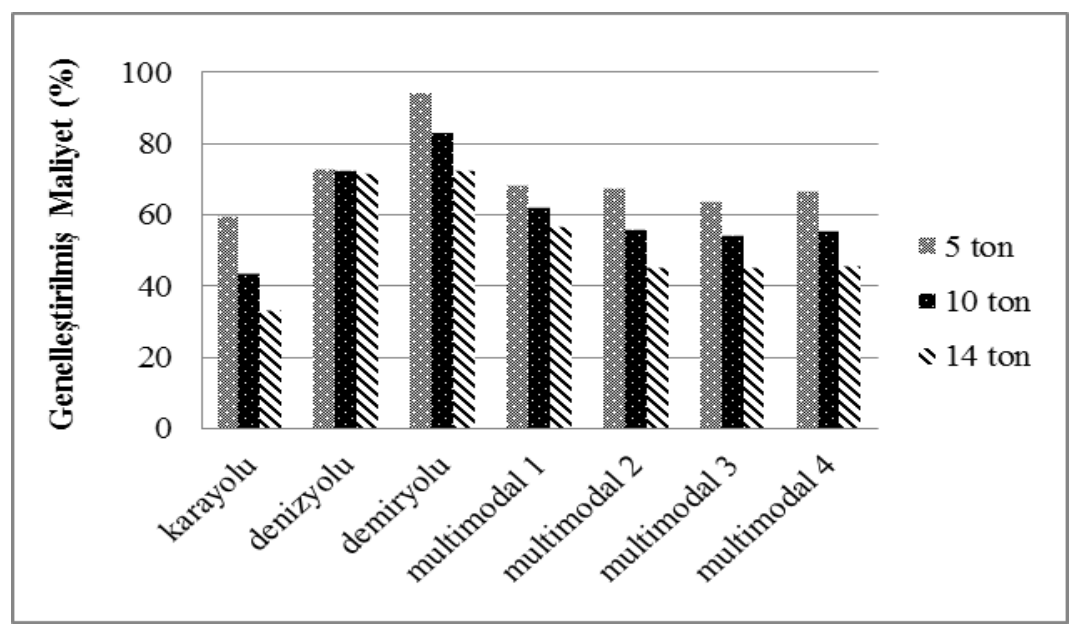

Şekil 5. Hatay-Tekirdağ performans indeksi.

\section{Sonuç}

Çalışmada ulaşım türleri için, performans kriterlerine göre yapılan rota karşılaştırılması çalışması sonuçları bu bölümde verilmektedir. Hatay-Tekirdağ arası oluşturulan rotalar, dört farklı karar değişkeni ve bu değişkenlerin hepsinin bir arada değerlendirildiği genelleştirilmiş maliyete göre karşılaştırılmaktadır. 
Yakıt tüketimi ele alındığında minimum yakıt tüketimi 20,19-20,74 litre dizel ile demiryolu ulaşım güzergâhında gerçekleşmektedir. Rotalar arasında en fazla yakıt tüketimi ise 371-58-411,88 litre dizel ile karayolunda hesaplanmaktadır. Taşımacılıktaki karayolunun payının diğer türlere aktarılması yenilenemez enerji kaynaklarından tasarruf etmede önemli etkiye sahip olmaktadır.

Rotaların maliyet değerlerine göre kıyaslaması yapıldığında minimum maliyet, 5ton yük için 698,06 TL ile unimodal demiryolu taşımacılığında, 10 ve 14 ton yük için 972,08 TL ve 1015,08 TL ile unimodal denizyolu taşımacılığında görülmektedir. Maliyet açısından en elverişsiz güzergâh ise 5 ton yük için 1920,08 TL ile karayolu, 10 ve 14 ton yük için sırasıyla 2177,36 TL ve 2865,22 TL ile multimodal 2 taşımacılık rotasıdır. Mod değişimine gerek duyulmayan, kapıdan kapıya taşımacılık için tercih edilen karayolu taşımacılığının maliyet açısından uygun olmadığı açık bir şekilde görülmektedir. Bu da taşımacılıkta karayolu ulaşım türünün tercihinin ciddi mali kayıplara sebebiyet verdiğini göstermektedir. Multimodal taşımacılık rotaları içerisindeki demiryolu taşımacılığı mali değeri yüksek olan yüklerin taşınması nakliye maliyetleri olumsuz yönde etkilenmektedir.

Taşımacılık süresine göre rotalar incelendiğinde, en hızlı rota 30,05 saat ile karayolu taşımacılık güzergâhıdır. Karayolu ile yapılan taşımacılıklarda yasal çerçevede sürücü dinlenme sürelerinden dolayı taşıma süreleri artmaktadır. Demiryolu taşımacılığında her ne kadar gecikmelere yol açacak insan faktörlü etmenler olmasa da, ara duraklarda meydana gelen zamansal kayıplardan dolayı taşımacılık süresi için olumsuz etkilenmektedir. Multimodal ve denizyolu taşımacılıklarında meydana gelen operasyonel zaman kayıpları taşımacılık sürelerini arttırmaktadır. Yük aktarma noktalarındaki süreçsel planlamaların düzenlenmesi ile multimodal ve denizyolu yük taşımacılık rotaları tercih edilebilir hale getirilebilir.

Rotalarda ulaşım türü araçlarına göre hesaplanan emisyon değerlerine göre en çevreci güzergah 5, 10 ve 14 ton yük taşınması için sirasıyla 154,79 gram,177,04 gram ve 190,39 gram ile denizyoludur. En fazla $\mathrm{CO}_{2}$ salınımı ise 5118,12 gram, 20472,48 gram ve 28689,57 gram ile karayolu taşımacılığında görülmektedir.

Dört karar değişkenine bağlı olarak hesaplanan genelleştirilmiş maliyet değerlerine göre performansı en yüksek güzergah \%94,35 - \%72,43 aralığında demiryolu taşımacılığı en iyi çıkmaktadır. En düşük performanslı rota ise \%59,27-\%33,01 ile karayolu taşımacılık güzergâhıdır. Genelleştirilmiş maliyet sonuçlarında görüldüğü gibi ülkemizde yoğun trafiğe yol açan ve ağır yüklerden kaynaklı olarak karayolu bakım onarım maliyetlerini yükselten karayolu yük taşımacılığının elverişsiz olduğu açıkça görülmektedir.

İleride yapılacak olan çalışmalarda, genelleştirilmiş maliyet hesaplarında bu çalışmada eşit ağırlıklı olarak alınan güzergâh karar değişkenleri, firmalar ile anket çalışması yapılarak yükün cinsine bağlı ihtiyaca göre ağırlıklandırılması yapılabilir. Bu şekilde karar değişkenlerinin katkısı zamana, yük cinsine bağlı olarak taşımacılık politikalarına göre esnek bir davranış gösterebilir. 


\section{Kaynaklar}

[1] Cansız, O. F., Göçmen, S., Distance analysis of multimodal transportation based on traveling salesman problem with particle swarm optimization method, International Journal of Advanced Engineering Research and Science, 5,6,1-6, (2018).

[2] Cansız, O. F., Ünsalan, K., Cost analysis of multimodal freight transportation : a case of 1skenderun, International Journal of Advanced Engineering Research and Science, 5,5, 315-319, (2018).

[3] Cansız, O. F., Ünsalan, K., Çalısıcı, M., Göçmen, S., Çok türlü taşımacılık güzergâhlarının gezgin satıcı problemleri baz alınarak tasarlanması: güzergâhların optimizasyonu ve akıllı ulaşım sistemlerine entegrasyonu, $\mathbf{1}$. Uluslararası Akılı Ulaşım Sistemleri Kongresi, Balıkesir, Türkiye, 58-59, (2018a).

[4] Cansız, O. F., Ünsalan, K., Çalısıc1, M., Göçmen, S. (2018b). Şehirlerarası güzergâh performans indeksinin çok türlü taşımacılık baz alınarak analiz edilmesi: analiz parametrelerinin oluşturulması ve aus entegrasyonu. 1. Uluslararası Akıllı Ulaşım Sistemleri Kongresi, Balıkesir, Türkiye, 213-214, (2018b).

[5] Cansız, Ö. F., Ünsalan, K., Çalışıcı, M., Göçmen, S., Şehirlerarası taşımacılık performansı indeksinin çok türlü taşımacılık baz alınarak analiz edilmesi: çok türlü güzergâhların tasarımı ve AUS entegrasyonu, 1. Uluslararası Akıllı Ulaşım Sistemleri Kongresi, Balıkesir, Türkiye, 5-8, (2018c).

[6] Cansiz, O. F., Polat, M. I., Analysis of public transport system, Hatay example: detection of existing system, International Journal of Advanced Engineering Research and Science, 5,5, 95-102, (2018).

[7] Tanır, B., Marmara Bölgesi'ndeki karayolu yük taşımacılığına alternatif kombine taşımacılık sistemlerinin araştırılması, Yüksek Lisans Tezi, Gazi Üniversitesi Fen Bilimleri Enstitüsü, Ankara, (2009).

[8] Öztürk, T., Türkiye diş ticaretinde kombine taşımacılık ve türki cumhuriyetleri analizi, Yüksek Lisans Tezi, İstanbul Üniversitesi Fen Bilimleri Enstitüsü, İstanbul (2010).

[9] Erdem, M.,Türkiye'de kombine taşımacılık için liman yerinin bulanık AHP ile seçimi, Yüksek Lisans Tezi, İstanbul Üniversitesi Fen Bilimleri Enstitüsü, İstanbul, (2012).

[10] Steadieseifi, M., Dellaert, N.P., Nuijten, W., Van Woensel, T., Raoufi, R., Multimodal freight transportation planning: A literature review, European Journal of Operational Research, 233, 1-15, (2014).

[11] Vural, D., Gencer, C., Karadoğan, D., Ulaştırma uygulamalarına yönelik çok modlu model önerisi, Savunma Bilimleri Dergisi, 13, 1, 75-105, (2014).

[12] Atar, F., Aydoğdu, Y. V., Duru, O., Şenol, Y. E., Kısa mesafe deniz taşımacılığının avantajları ve kombine taşımacılıktaki önemi üzerine bir çalışma, Dokuz Eylül Üniversitesi Denizcilik Fakültesi Dergisi, 5, 1, 75-91, (2013).

[13] Petraska, A., Ciziuniene, K., Prentkovskis, O., Jarasuniene, A., Methology of selection of heavy and oversized freight transportation system, Transport and Telecommunication, 19, 1, 45-58, (2018).

[14] Woo, S. H., Kim, S. N., Kwak, D. W., Pettit, S., Beresford, A., Multimodal Route Choice in Maritime Transportation: The Case of Korean Auto-Parts Exporter, Maritime Policy\&Management, 45, 1, 19-33, (2018).

[15] Basu, R., Verma, M., An Expected Consequence Approach to Assessing the 
Viability of Multimodal Transportation of Crude Oil in Eastern Canada, Case Studies on Transport Policy, 5, 3, 518-526, (2017).

[16] Hanssen, T.E.S., Mathisen,T.A., Jorgensen, F., Generalized transport costs in intermodal freight transport, Procedia-Social and Behavioral Sciences, 54, 189-200, (2012).

[17] Janic, M., Modelling the full costs of an intermodal and road freight transport network, Transportation Research Part D: Transport and Environment, 12, 1, 33-44, (2007).

[18] Du, Q., Kim, A. M., Zheng, Y., Modeling multimodal freight tranportation scenarios in northern canada under climate change 1mpacts, Research in Transportation Business\&Management, 23, 86-96, (2017).

[19] Fremont, A., Franc, P., Hinterland transportation in europe: combined transport versus road transport, Journal of Transport Geography, 18(4), 548-556, (2010).

[20] Arnold, P., Peeters, D., Thomas, I., Modelling a rail/road intermodal transportation system, Transportation Research Part E: Logistics and Transportation Review, 40, 3, 255-270, (2004).

[21] TÜİK, Sektörlere ve kullanım alanlarına göre nihai enerji tüketimi, (2005a).

[22] Atar, F., Kısa mesafe deniz taşımacılığının avantajları ve kombine taşımacılıktaki önemi, Yüksek Lisans Tezi, İstanbul Teknik Üniversitesi Fen Bilimleri Enstitüsü, İstanbul, (2013).

[23] http://www.ustaokan.com/?Syf=26\&Syz=530815, (22.05.2018).

[24] http://www.nasmaritime.com/kitap/KONTGEM-15112010-SNAS.pdf, (15.05.2018).

[25] http://www.denizhaber.com/konteyner-gemileri-ve-siniflandirilmalarimakale, 100390.html

[26] https://portal1.tcddtasimacilik.gov.tr/tcdd(bD10ciZjPTIwMCZkPW1pbg==)/zy0 2/yuk_tasima_fiyatlari, (10.02.2018).

[27] TCDD (2018). TCDD Liman Hizmetleri Tarifesi.

[28] Ballou, R. H., The evolution and future of logistics and supply chain management, Browse Journals\&Books, 19,4,332-348, (2004).

[29] https://www.tugem.com.tr/mevzuat?mlid=2528, (28.04.2018).

[30] http://www.kgm.gov.tr/Sayfalar/KGM/SiteTr/Trafik/HizSinirlari.aspx, (20.05.2018).

[31] https://railturkeyakademi.wordpress.com/2015/04/08/demiryolunda-rekabetcicozumler-hizli-trenler/\#more-399, (29.04.2018).

[32] TÜİK, Ekonomik Faaliyetlere Göre Hava Emisyon Hesapları, (2015b).

[33] http://www.cefic.org/Industry-support/Responsible-Care-tools-SMEs/5Environment/Guidelines-for-managing-CO2-emissions-from-transportoperations/, (20.04.2018).

[34] Punakivi, M. \& Hinkka, V., Selection criteria of transportation mode: A case study in four finnish industry sectors. Transport Reviews, 26 (2), 207-219., (2006). 